Addiction Research 6:131-145, 1998.

\title{
MUTUAL HELP MOVEMENTS FOR ALCOHOL PROBLEMS IN AN INTERNATIONAL PERSPECTIVE
}

\author{
Robin Room \\ Addiction Research Foundation \\ 33 Russell Street \\ Toronto, Ontario M 5S 2S1, Canada
}

\begin{abstract}
$M$ utual-help groups in the alcohol field were first organized 150 years ago, and some European groups continue from the late 19th century. A fter the Second W orld War, Alcoholics A nonymous (AA) began to spread internationally, and new national mutual help movements were founded, to some extent drawing on or reacting to the AA model. While AA is dominant in North A merica and many English-speaking countries, other mutual-help movements are stronger in such countries as France, Germany, Italy, Sweden and Japan. Several dimensions of differentiation between the movements are discussed, including: professional or institutional sponsorship vs. autonomous organization; the movement's religious, spiritual or secular basis; whether family members and others are members as well as alcoholics; whether there are external affiliations and activities; and patterns of internal organization and functioning.
\end{abstract}

The alcohol field is unusual among health or social service fields in the long continuation and strength of its mutual-help movements. In many societies, these movements reach at least as broadly into the population as any organized professional effort in the field, and sometimes more broadly. This can be illustrated from general population surveys in each of the three main countries of North A merica. In the U.S., more than half of those who ever sought help with an alcohol problem of their own went to Alcoholics A nonymous -- considerably more than ever sought help from a formal alcohol treatment program, or from a physician or health worker (Weisner et al., 1995). When asked what treatment for alcohol problems they would recommend if a friend or relative asked their advice, four-fifths of M exicans in the Tlalpan district of M exico City recommended A A (Rootman and M oser, 1985:96). A mong those in Ontario, Canada who had actually recommended help to a relative, friend or acquaintance in the preceding year, as many recommended AA or another mutual support group as recommended any kind of professional or institutional help (Room et al., 1996).

In this discussion I have chosen to use the term "mutual help movements", while the more usual term in studies of the phenomenon is "self help" (e.g., Katz, 1993; Katz and Bender, 1976). "Self-help" tends to imply the individual is acting by him- or herself, whereas group process and mutual support are at the heart of the movements we are considering.

The largest and best-known mutual help movement in our field, of course, is A lcoholics A nonymous. This paper in part draws on the work of the recently-concluded International 
Collaborative Study of Alcoholics Anonymous (ICSAA). ICSAA was organized as an autonomous group of scholars from eight countries: Finland, Sweden, Iceland, Poland, Switzerland, M exico and the U nited States, with Klaus M äkelä serving as the study coordinator. In the jointly-authored book from the project (M äkelä et al., 1996), we set out to analyze what varied and what stayed constant in A A as it became rooted in very different societies. We did, indeed, find differences from one society to another, but also impressive commonalities; in large part, over more than half a century and in dozens of societies, AA has stayed true to its original organizational principles as a social movement, to its belief system, and to a well-developed system of interactions in regular meetings and other social ties.

The ICSA A project will also result in a second volume of case studies of A A in the eight societies, edited by Pia Rosenqvist and Irmgard Eisenbach-Stangl (see also E isenbach-Stangl and Rehm, 1992). But as often with such projects, its existence also stimulated a outpouring of related work, including work on other mutual help movements. This included studies of the relations between A A and professional treatment (Eisenbach-Stangl and Rehm, 1994), of the international dissemination of "12-step treatment" as a model of institutional alcohol treatment, of Polish A bstainer Clubs, of Links in Sweden, of several national mutual-help movements which are members of Sobriety International, of Women for Sobriety, and of the emergence in the U.S. of a generalized 12-step consciousness (see Rosenqvist, 1991 and Room and Rehm, 1992). In the wake of the ICSAA project, an international conference on Addiction and Mutual $\mathrm{Help}$ M ovements in a Comparative Perspective was held in Toronto on September 12-16, 1994. The 37 papers by scholars from 13 countries discussed and compared features of a number of other mutual-help movements as well as AA. ${ }^{1}$ This paper also draws on this broad range of recent work on mutual help groups in the addictions field.

\section{MUTUAL HELP MOVEMENTS IN THE ALCOHOL FIELD: BEFORE AA AND SINCE}

The history of organized mutual help groups in the alcohol field extends back 150 years, to the Washingtonians and similar groups in the U.S. of the 1840s and 1850s (Blumberg and Pittman, 1991; Baumohl, 1986). In Europe as in North A merica, many of the temperance organizations of the late 19th century included reformed drunkards among their members. In parts of Europe, organizations such as the Blue Cross and Gold Cross founded in that era continue a vigorous existence today.

The modern era of mutual help movements in the alcohol field begins with the founding of Alcoholics A nonymous in the U.S. in 1935. A lcoholics A nonymous grew rather slowly in its early years, to about 100 members in 1939, and remained relatively unknown even in the U.S. until it received national publicity in 1941. A part from a couple of small-scale earlier attempts, successful efforts to found AA groups outside the U.S. began only at the end of the Second W orld War.

A variety of other mutual-help movements and organizations have grown up in the alcohol field since 1945. M any of them have quite different methods of organization and functioning from $A A^{\prime}$ 's. But it is difficult to find any example of a mutual-help or self-help movement dealing with alcohol or drug problems initiated in the last 50 years which was not influenced, positively or negatively, by the example of AA. Particularly in earlier years, the influence might be remote

${ }^{1}$ Selected papers from the conference, in revised form, were published in a special issue of Contemporary Drug Problems (vol. 23, no. 1, 1996) edited by Alan Ogborne. 
and nonspecific -- simply the news that a mutual-help movement of recovering alcoholics existed and was reported to be successful. Thus a 1945 article on A A in the Swedish Reader's Digest contributed to the initiation of what became the Swedish Links movement (Kurube, 1992). Tomofumi Oka notes that the Japanese national al coholic self-help movements were formed when a leader of a long-established Japanese temperance group "noticed the existence of Alcoholics A nonymous", and wrote about it in the group's newsletter in 1950 (Oka, 1994). One of the two organizations which joined to become the F rench mutual-help movement V ie Libre, for workingclass alcoholics and their families, was formed by an antabuse-prescribing doctor and the recovered drinkers he cared for, as A lain Cerclé puts it,

"following the example of AA (of which a group existed already in Paris)" (Cerclé, 1985).

In later years, the influence has usually been direct: the founders of a national mutual-help movement have usually adopted or adapted parts of AA's ideology or program while implicitly or explicitly rejecting other parts. This is true also for the three main alternative mutual-help movements to AA in the U.S., Rational Recovery Systems (founded 1986, reporting 350 groups), Secular Organizations for Sobriety (also known as Save Our Selves and SOS, founded 1986, reporting 1000 groups), and Women for Sobriety (founded 1976, reporting 350 groups). ${ }^{2}$ A fter interviewing the authors of the primary texts of each of these movements, Charlotte Kasl (1992:163) remarks that all three

were pioneering souls who attended AA and left for various reasons, including dislike of the sexism, the powerlessness concept, rigidity, religiosity, the cult-like atmosphere, and the all powerful God approach.

In N orth A merica, of course, A lcoholics A nonymous retains its dominance of the mutualhelp scene for alcohol problems, with over 50,000 groups. But this is by no means the case everywhere. In F rance, Cerclé reports, only about $11 \%$ of ex-alcoholics in mutual help groups are in AA, with the remainder in four other movements (M äkelä et al., 1996); in Italy there are at least four times as many groups of the Clubs for A lcoholics in Treatment (CATs) as there are A A groups, and at least half again as many alcoholics in CATs as in A A (Allamani, 1994 and personal communication); in Japan AA groups are less than one-third of all mutual help groups (O ka, 1994), and in the state of Hesse in Germany there are three times as many groups in the traditional temperance-based organizations, and as many groups in a newer mutual-help movement, Freundeskreise, as there are AA groups (A ppel, 1996). Other countries in which national or temperance-based mutual-help movements are dominant or important include Croatia, Switzerland, Poland, Sweden and Denmark.

D rawing on recent studies, Table 1 gives approximate relative sizes of mutual help groups for alcohol problems in selected societies. The percentages in the table should be treated with some caution, since they reflect membership claims of organizations which apply different criteria for membership. As the example of Japan shows, a comparison based on size of membership may yield different figures from a comparison based on number of groups. The table underlines the necessity of paying attention to more than AA in discussing in an international perspective mutual help groups in the alcohol field. On the other hand, it should be kept in mind that there are a number of countries -- Iceland, A ustralia and New Zealand would be examples -- where A A's dominance of the mutual-help scene is even greater than in the U.S. and Canada.

Where there is more than one strong mutual-help movement for the same problem, a

${ }^{2}$ The dates of founding and numbers of groups are from W hite and M adara, 1992. 
certain amount of organizational competition is inevitable. But public antagonism seems to be unusual. Even in Sweden, where the Links movement has fractionated into seven different organizations and where AA membership grew strongly in the 1980s along with the advent of $M$ innesota M odel treatment institutions, N oriko K urube notes that "the relationship between the Links and AA in Sweden seems peaceful and without serious conflicts" (Kurube, 1992). Sometimes the relation between movements is closer and even symbiotic, as Graiyna Ctwi ${ }^{1}$ tkiewicz (1992) reports has been true for the Abstainer Clubs and A A in Poland. Often the movements tend to divide the market of potential recruits by appealing to different population segments: for instance, compared to the national movement, AA seems to appeal to the better off in Sweden, and to the less well-off and to the uncoupled in Japan (K urube, 1992; Oka, 1994). A the level of the individual members, overlapping active membership seems to be common even where the movements are in clear ideological conflict. Thus Kaskutas (1992a) found that $29 \%$ of members of Women for Sobriety, a primarily North A merican movement based on a feminist critique of A A's ideology, also concurrently attend AA. Likewise, Connors and Dermen (1994) found 35\% of members of SOS -- a movement aiming to provide a secular alternative to AA's spiritual emphasis -- planned to continue attending A A as well as SOS.

\section{TOWARDS A TAXONOMY OF MUTUAL-HELP MOVEMENTS IN ADDICTIONS}

The recent spate of studies of mutual-help organizations for alcohol problems allows us to begin to define dimensions of differentiation between the various movements. In this discussion, I will use AA as the index case to which other movements are compared. There are several reasons for this. One is the ubiquity of $A A$ : C roatia may provide a unique example of a country with a strong mutual-help movement for alcohol problems but with little AA activity. A second reason, al ready remarked on, is the influence of the example of $A A$ in the formation of other mutual-help movements since the Second W orld War. Related to this, the example of A A also seems to exert a continuing influence on other movements, including those with older roots: thus A ppel (1994) remarks that "many features of A A meetings and beliefs have been incorporated as well in the other [German] groups.... The knowledge of [A A's] democracy however poses a challenge to the ... very hierarchical structures within the abstinence organizations". A further reason for using AA as the index case is the clear bench-mark it has set, in its Twelve Traditions and in its other organizational principles and practices (Room, 1993), at one end of a number of different dimensions on which other mutual-help organizations are differentiated.

Professional/institutional sponsorship vs. autonomous organization:

Whether the mutual-help group is professionally or institutionally sponsored or is autonomously organized by ex-alcoholics or addicts is probably the single most important dimension of differentiation between mutual-help organizations, since it carries with it many implications in terms of such issues as ideology, autonomy, hierarchical or egalitarian relations within the movement, and financing. AA is, of course, the archetype of the lay-led autonomous organization. But the AA story on this issue is actually quite complex. Even in the U.S., friendly professionals played an important role in AA's early development -- and one of the co-founders was a medical doctor who used his prerogatives as a physician to help other alcoholics. In the majority of the other societies studied by the ICSA A project, professionals played an important role as initiators or supporters of the first A A groups (M äkelä, 1993), and elsewhere the spread of institutional 12-step treatment -- the "M innesota M odel" -- has played an important role in 
A A's growth (Stenius, 1991).

In other mutual-help movements, however, the role of professionals has often been much more directive and determinative than anywhere in AA. The benchmark case here might be Croatia (and, more generally, former Y ugoslavia) (Poldrugo et al., 1994). The first Club of Treated Alcoholics was started in 1964 by staff of a treatment hospital in Zagreb under the direction of Dr. Vladimir Hudolin. From the first, the developing network of clubs was seen as part of a continuum of professional treatment and aftercare for alcoholics (Hudolin, 1984). The Clubs (sometimes known as "Hudolin groups") spread under professional sponsorship all over Croatia and eventually elsewhere in Y ugoslavia and Italy. Each group session was led by a trained professional or semi-professional, often with other therapists also working regularly in the group (M atijeviæand Paunoviæ 1973).

In the Y ugoslavian Communist system, the professionals involved were paid for their work with the clubs. As Hudolin (1984) put it, "it is hard to imagine that a professional could regularly and permanently get engaged on a voluntary basis... This activity should be a part of his regular working hours or it should be paid extra". But with the change in system and the ensuing economic difficulties, "public funds for rehabilitative programs were drastically reduced". As a result, Thaller and his associates (1994) report, on the one hand the "number of self-help groups decreased", but on the other hand, "the organization of the Clubs is becoming more independent and economically self-sufficient". Ctevi ${ }^{1}$ tkiewicz (1992) reports a somewhat parallel development for the Polish A bstainer Clubs.

Both in Poland and in Italy, observers report a move on the part of the national clubs movement towards somewhat greater autonomy from professional oversight. This move may have been influenced in both countries by the context of an upsurge in A A membership. In 1989 the Warsaw Abstainer Clubs proposed a distinction between patient clubs and self-help abstainer clubs, noting that moves toward autonomy by the abstainer clubs had been frustrated by doubts of the professionals who sponsored the clubs "whether al cohol-dependent persons could be trusted and whether they could manage money and material goods" (đFi i ${ }^{1}$ tkiewicz, 1992). Bazzani and his colleagues (1994) report that there has been an evolution in the definition of the role of the facilitator in the Italian Clubs for Alcoholics in Treatment, from "therapist" to "catalyst" to "servant" of the group. While the Clubs had sometimes been integrated into the structure of social- or health-service institutions, a situation in which they are "of course ... not self-sufficient or autonomous", in recent years "a debate has arisen within the [Club] system regarding the two contrasting needs: the need to be in the community as an autonomous body, and the need to work with or next to the social-health services,... thus running the risk of having the self-help concept manipulated".

\section{A religious, a spiritual or a secular basis}

The main traditional temperance-based mutual-help organizations in continental Europe were by origin also explicitly Christian and denominationally linked, either to $\mathrm{C}$ atholicism (C roix d'Or, Kreuzbund) or to Protestantism (Croix Bleu, Blaues Kreuz), although religious adherence is often not required of members. Despite its spiritual emphasis, AA represented a step away from a direct connection between mutual help and religion; Cerclé (1985) reports that the founders of Vie Libre, while taking inspiration from AA, had found the Croix d'Or too traditionally "moralizing". The noncreedal and indeed not explicitly Christian nature of AA has given rise in $\mathrm{N}$ orth A merica to an explicitly Christian mutual-help movement, "Overcomers, Victory Through 
Christ" (White and M adara, 1992).

From the other side of the spectrum, the spiritual emphasis in AA's Twelve Steps program proved to be a repeated stumbling-block to the acceptance of $A A$, since it collided with the commitment to secularism of descendants of the European Enlightenment -- including many doctors and other treatment professionals as well as M arxists. A major differentiation between Swedish $L$ inks and AA is the downplaying of reference to a Higher Power in the Seven Points of Links, otherwise adapted from the Twelve Steps (K urube, 1992). In a Japanese context, Oka reports (1994), AA's spiritual roots seem very Judeo-Christian; the concept of "Higher Power" is not a part of Japanese vocabulary. Allamani (1994) notes that the relationship between AA and Italian health institutions was long "far from optimal" because until recently "physicians were skeptical of and not attracted by the spiritualism of the twelve-step program". Conversely, one of the attractions of the Clubs movement to physicians was that "their approach, initially nonspiritual, was more acceptable to the medical paradigm".

Basis of membership: alcoholics, family members, others

Although A A meetings in the early days of the movement often included the wives of alcoholics, the formation of AI-A non in 1951 for members of alcoholics' families settled the issue that membership in AA was for the alcoholic as an individual. From the first, AA had also been clear that, while it welcomed professional and other friends, they were not AA members. A lthough A A's ideology is in many ways an attack on rampant individualism, on what it terms "self will run riot" (Room, 1993), AA thus presumes an individuation on the part of the member, a sense of an individual identity distinct from family identification.

In contrast, family members, and often also professionals and interested volunteers, are accepted as members in several mutual-help movements in central and southern Europe -- for instance, in the temperance-based groups, in V ie Libre, and in the Clubs movements in Croatia and Italy. V ery likely, the inclusion of the family in these movements reflects cultural differences from the $U$ nited States in the relation of the individual and family. Changes in this relation may be one factor in the increased strength of A A in countries like Italy.

Perhaps the most explicit challenge to a presumption of individuation is in the written Traditions of the small J apanese mutual-help movement known as D anshu-Tomo-no-Kai or Dan$\mathrm{Yu}$, which quote a Japanese proverb: "we think that a married couple should be one body" (Oka, 1994). Both in this movement and in the larger A II Nippon Sobriety A ssociation or Danshukai movement, also largely male-oriented, the wife of the alcoholic is expected to participate along with the alcoholic. Oka (1994) notes that the male orientation and couple-centredness of the national Japanese movements have created an opening for the recent growth of AA in urban Japan, since women and the single and divorced are not organizationally marginalized in AA. This organizational characteristic may al so have created a place for A A in F rance, despite the existence of a number of indigenous movements. In a survey of members of the French mutual-help movements in the early 1970s, A A members were younger, less likely to be married, and much more likely to be women (30\%) than members of Vie Libre (5\%) or of the Croix d'Or (10\%; Benichou and Orsel, 1973:125).

\section{External relations and activities}

We have already noted that many mutual-help movements accept state subventions or other external funding. The principle that A A would not accept such funding was established early in 
AA 's history, and has been largely adhered to (M äkelä et al., 1996). As the recent history in Poland and Croatia underlines, where movements have depended on such financing, its removal can pose a serious predicament. Public financing also tends to weaken the autonomy and voluntarism of social movements. Oka (1994) notes this has been the effect in other fields of the Japanese administrative tradition of coopting self-help groups, and is concerned that it may also happen in the alcohol field.

A common ambition of mutual-help movements in the alcohol field has been to set up residential services for alcoholics. The founders of AA in the U.S. flirted with seeking funds to set up hospitals for alcoholics, but the AA traditions eventually established the principle that any such effort should be organizationally separate from A A. The first big split in the Swedish Links movement came over the decision to set up a convalescent home supported by state grants, a decision which necessitated a formal organizational structure and created a role for oversight by the state (K urube, 1992). A major distinguishing mark of the two "24-H ours M ovements" which split off from AA in M exico was the commitment to set up "annexes" -- rooms for sobering up and for shelter -- to their meetings, and soon after also "rehabilitation farms" for alcoholics (Rosovsky, 1994). State cooptation was not involved in this case; rather, the movements were responding to a need not met by the national welfare and health system.

$M$ utual help movements in the alcohol field have generally kept out of partisan politics. A gain, A A takes a stand at one end of the spectrum on this; its Traditions forbid any external affiliations or endorsements. A few mutual-help movements in the alcohol field have involved themselves in political activity, particularly on matters related to alcohol controls or treatment. $V$ ie Libre has taken an unusually expansive line on its field of political interest, taking as one of its aims struggling "against the social and political causes of alcoholism". Its 1976 congress, for instance, adopted resolutions calling for a ban on gambling games in cafes, for a reduction in the price of non-alcoholic drinks, and for an increase in the health budget (Cerclé, 1985).

\section{Internal organization and functioning}

A A has maintained a radical commitment to a number of principles which, as Bufe (1991) has remarked, carry into practice the organizational ideals of classical anarchist thought. A A groups are self-starting and self-governing; there is no franchise system which allots territories or population segments to any group, and groups are autonomous and financially independent (M äkelä et al., 1996). Except for the copyrights on its publications, AA as a movement owns no property. Though little is available in the international literature on these matters for other movements, there is clearly substantial variation. Women for Sobriety, for instance, operates on a franchise system, with a moderator for each group certified by the organization's headquarters (K askutas, 1992b). Formal membership criteria and organizational structures are typical of the temperance-based movements and of Swedish Links. It is unlikely that many other movements share with AA a prohibition on owning buildings or land.

There appears also to be substantial variation in what happens and in styles of discourse at group meetings. A t a regular A A meeting, everything said should in principle be related to one's own drinking history or one's struggle to stay sober. In contrast, relating one's drinking history is discouraged at Women for Sobriety meetings, and the meeting is organized around first a discussion of a preset topic and then a round of participants reporting on the experiences of their week (Kaskutas, 1989). AA's rule of "no crosstalk" -- that participants should not directly comment on each other's contributions -- contrasts sharply with the confrontational discourse in 
much professional 12-step treatment ( $M$ äkelä et al., 1996) and with discourse in meetings of the M exican 24-Hours M ovements, which "practice a direct aggressive therapy" where, Rosovsky (1994) notes, "the use of foul language" is considered "therapeutic for the alcoholic".

Scattered observations in the literature give us hints of some other differences between movements in what goes on at their meetings. While A A is remarkable among social movements in its complete avoidance of songs or anthems, the meetings of the Japanese movement A NSA conclude with a chorus of the movement's Sobriety Song (Oka, 1994). In her observations of Club meetings in Croatia in the early 1980s, Linda Bennett (1984) notes a rather different spirit from an $A$ A meeting:

No one is anonymous: a membership roster is kept, and a roll is taken at each meeting....Each member takes antabuse [disulfiram] ... over the first year. As names are read from the roll, each alcoholic goes to the front of the room where a tray of glasses and pills have been placed and takes a pill.

Much could be learned from explicitly comparative studies of the actual process and functioning of the different mutual help groups.

\section{CONCLUSION}

The experience of many societies teaches us that mutual help movements provide much of the backbone for an effective societal response to drinking problems. The long-term effects of substantial mutual help activity in a society may well be more significant than the effects of professional treatment activities and of formal availability control systems.

The recent literature on mutual help groups in the alcohol field gives us a sense of the richness of variation and experience which can be tapped by comparative analysis, looking both across movements and across societies. We can al ready discern, from the work so far available, tantalizing glimpses of the scope of variation between movements on various dimensions, and of the ways in which particular organizational choices are fateful, tending to place the organization also on a number of other dimensions.

But much remains to be done. The recent work allows us to begin to enumerate a number of significant dimensions and characteristics for a full comparative study. But the data so far available is selective indeed. Filling in the blanks and undertaking a full comparative analysis is a worthy task for future collaborative international work.

\section{REFERENCES}

A llamani, A llaman (1994) A Icoholics A nonymous and 12-Step movements in Italy, presented at an international conference on Addiction and $M$ utual Help Movements in a Comparative Perspective, Toronto, 12-16 September.

A ppel, Christa (1994) Context and content of the discourse on self-help in Germany, presented at an international conference on Addiction and $M$ utual Help Movements in a Comparative Perspective, Toronto, 12-16 September.

A ppel, Christa (1996) Different stories: self-help groups for alcoholics and illicit drug users in Germany, Contemporary Drug Problems 23:57-75. 
Baumohl, James (1986) On asylums, homes, and moral treatment: the case of the San Francisco Home for the Care of the Inebriate, 1859-1870, Contemporary Drug Problems 13:395-445.

Bazzani, O., V. Patussi, A. Quatini and C. Surrenti (1994) M utual/self help groups for treatment of alcohol problems: cooperation/competition, presented at an international conference on A ddiction and M utual Help M ovements in a Comparative Perspective, Toronto, 12-16 September.

Benichou, Lionel and Claude Orsel (1973) Groupes d'entraide et de soutien chez les alcooliques et les usagers d'autres drogues, rapport d'assistance présenté au Congrès de Psychiatrie et de Neurologie de langue Francaise, LXX le Session - M onaco - 2 au 7 ] uillet 1973 [M utual help and support groups among alcoholics and users of other drugs... ], Paris: Masson.

Bennett, Linda (1984) Treating alcoholism in a Yugoslav fashion, East European Quarterly 18:495-519.

Blumberg, Leonard U. and William L. Pittman (1991) Beware the First Drink! The Washingtonian Temperance M ovement and Alcoholics A nonymous, Seattle: Glen A bbey Books.

Bufe, Charles (1991) Alcoholics A nonymous: Cult or Cure?, San Francisco: See Sharp Press.

Cerclé, Alain (1985) L'analyse descriptive des mouvements d'anciens buveurs [Descriptive analysis of movements of ex-drinkers]. Rennes: U niversité Rennes II. ["Extraits de ma thèse de doctorat, L'identité de l'ancien malade alcoolique membre actif d'une association d'entraide: abstinence militante et restructuration identitaire, Prix Robert Debré 1985, Paris: Haut Comité d'Études et d'Information sur l'Alcoolisme, 2 vols." ]

Connors, Gerard J. and Kurt H. Dermen (1994) SOS: the emergence of a secular self-help organization, presented at an international conference on Addiction and $M$ utual Help M ovements in a Comparative Perspective, Toronto, 12-16 September.

Eisenbach-Stangl, Irmgard (1996) Belief in medicine and belief in God: self-help of alcoholics and AA in A ustria, Contemporary Drug Problems 23:11-28.

Eisenbach-Stangl, Irmgard and Jürgen Rehm, eds. (1992) Trunksucht und Selbstreform: Die Gemeinschaft der A nonymen Alkoholiker in Deutschland, Österreich, der Schweiz und Italien [A ddiction and self-reform: the society of AA in Germany, A ustria, Switzerland and Italy], special issue of Drogalkohol 16:141-226.

Eisenbach-Stangl, Irmgard and J ürgen Rehm, eds. (1994) Die A nonymen A lkoholiker und das Professionelle Behandlungssystem [A A and the professional treatment system], thematic issue of Wiener Zeitschrift für Suchtforschung, 17(1/2):1-87.

Hudolin, Vladimir (1984) The alcoholism programme at the University Department for Neurology, Psychiatry, A lcohology, and Other Dependencies, «Dr. M. Stojanoviæ U niversity Hospital, Zagreb", Alcoholism (Zagreb) 20:3-51. 
Kaskutas, Lee (1989) Women for Sobriety: a qualitative analysis, Contemporary Drug Problems $16: 177-200$.

Kaskutas, Lee Ann (1992a) An A nalysis of "Women for Sobriety". D r.P.H. dissertation, School of Public Health, University of California, Berkeley.

Kaskutas, Lee (1992b) Beliefs on the source of sobriety: interactions of membership in Women for Sobriety and A Icoholics A nonymous, Contemporary Drug Problems 19:631-648, 1992b.

Kasl, Charlotte Davis (1992) M any Roads, One Journey: M oving Beyond the 12 Steps. N ew York: Harper Perennial.

Katz, Alfred H. (1993) Self-help in A merica: A Social M ovement Perspective, N ew Y ork: Twayne Publishers.

Katz, Alfred H. and E.I. Bender (1976) Self-help groups in Western society: history and prospects, Lournal of Applied Behavioral Science 12:262-282.

K urube, Noriko (1992) The ideological and organizational development of the Swedish Links movement, Contemporary Drug Problems 19:649-676.

Mäkelä, Klaus (1993) Implications for research of the cultural variability of Alcoholics A nonymous, pp. 189-208 in: Barbara S. M CCrady and William R. M iller, eds., Research on Alcoholics A nonymous: Opportunities and Alternatives, N ew Brunswick, NJ: Rutgers Center for Alcohol Studies.

M äkelä, Klaus, Ilkka A rminen, Kim Bloomfield, Irmgard Eisenbach-Stangl, Karin Helmersson Bergmark, N oriko Kurube, Nicoletta M ariolini, Hildigunnur Ólafsdóttir, J ohn H. Peterson, M ary Phillips, Jürgen Rehm, Robin Room, Pia Rosenqvist, Haydée Rosovsky, Kerstin Stenius, Grąyna CFri ${ }^{1}$ tkiewicz, Bohdan Woronowicz and Antoni Zieliñski (1996) Alcoholics A nonymous as a Mutual-H elp M ovement: A Study in Eight Societies. M adison: U niversity of Wisconsin Press.

M atijeviæ I. and N. Paunoviæ(1973) Rehabilitation of alcoholics in a club of treated alcoholics, Alcoholism (Zagreb) 9:50-54.

Oka, Tomofumi (1994) Self help groups of J apanese alcoholics: their movements and cultural influences, presented at an international conference on Addiction and $M$ utual $\mathrm{Help}$ M ovements in a Comparative Perspective, Toronto, 12-16 September.

Poldrugo, F., D. Breitenfeld, V. Patussi, V. Thaller and S. Pintaric (1994) The development of self-help groups for the treatment of alcoholism in Italy and Croatia: a cross-cultural analysis, presented at an international conference on Addiction and Mutual Help Movements in a Comparative Perspective, Toronto, 12-16 September.

Rehm, Jürgen and Robin Room, eds. (1992) M utual help for alcohol-related problems: studies of 
AI-A non and of alternatives to Alcoholics A nonymous, thematic issue of Contemporary Drug Problems 19:555-740.

Room, Robin (1993) Alcoholics A nonymous as a social movement, pp. 167-187 in: Barbara S. M cCrady and William R. M iller, eds., Research on Alcoholics A nonymous: Opportunities and Alternatives, N ew Brunswick, NJ: Rutgers Center of Alcohol Studies.

Room, Robin, Susan Bondy and J acqueline Ferris (1996) D eterminants of suggestions for alcohol treatment, Addiction 91:643-655.

Rootman, Irving and Joy M oser (1985) Community Response to Alcohol-Related Problems, Washington, DC: USGPO, DHEW Publication No. (ADM) 85-1371.

Rosenqvist, Pia (1991) A A, A I-A non and gender, Contemporary Drug Problems 18:687-706.

Rosovsky, Haydée (1994) A strong but fragmented movement: the case of AA in Mexico, presented at an international conference on Addiction and $M$ utual Help Movements in a Comparative Perspective, Toronto, 12-16 September.

Stenius, Kerstin, (1991) "The most successful treatment model in the world": introduction of the M innesota M odel in the Nordic countries, Contemporary Drug Problems 18:151-179.

Ctrvi tkiewicz, Graiyna (1992) Self-help abstainer clubs in Poland, Contemporary Drug Problems 19:677-687.

Thaller, V., D. Breitenfeld, J. Ivica, S. Pintariæa D. Buljan and F. Poldrugo (1994) Self-help groups of alcoholics and war in Croatia, presented at an international conference on Addiction and M utual Help M ovements in a Comparative Perspective, 12-16 September.

Thiollière, E. (1968) La Croix d'Or Française, Alcoholism (Zagreb) 4:9-13.

W eisner, Constance, Thomas Greenfield and Robin Room (1995) Trends in the treatment of alcohol problems in the US general population, 1979 through 1990, A merican Journal of Public Health 85:55-60.

White, Barbara J. and Edward J. M adara, compilers and editors (1992) Self-H elp Sourcebook: Finding and Forming M utual Aid Self-H elp Groups, fourth edition. Nutley N J: A merican SelfHelp Clearinghouse. 
Table 1. A pproximate relative size of mutual help groups for alcohol problems, by number of groups, selected societies

\begin{tabular}{|l|c|c|c|l|}
\hline Society and date & $\begin{array}{c}\text { A lcoholics } \\
\text { A nonymous }\end{array}$ & $\begin{array}{c}\text { Denominational } \\
\text { \&/or } \\
\text { temperance- } \\
\text { based groups }\end{array}$ & $\begin{array}{c}\text { Other } \\
\text { mutual } \\
\text { help } \\
\text { groups }\end{array}$ & References \\
\hline F rance, late 1980s & $11 \% * *$ & $41^{* *}$ & $48 * *$ & M äkelä et al., 1996:207 \\
\hline $\begin{array}{l}\text { Hesse, Germany, } \\
1990\end{array}$ & $17 \%$ & 53 & 30 & A ppel, 1996 \\
\hline Italy, c. 1995 & $14 \%$ & $* * *$ & 86 & $\begin{array}{l}\text { Allamani \& Petrikin, } \\
1996 \text { \& personal } \\
\text { communication }\end{array}$ \\
\hline Sweden, 1990 & $24 \%$ & $* * *$ & 76 & $\begin{array}{l}\text { Kurube, 1992 \& } \\
\text { personal communication }\end{array}$ \\
\hline Japan, 1993 & $\begin{array}{l}32 \% \\
\text { [c. } 14 \% * *]\end{array}$ & $* * *$ & 68 & $\begin{array}{l}\text { Oka, 1994 } \\
\text { Oka, 1994 }\end{array}$ \\
\hline Poland, c. 1991 & c. $47 \% * *$ & $* * *$ & C. 53** & Swiatkiewicz, 1992 \\
\hline A ustria, 1993 & $50 \%$ & 5 & 45 & Eisenbahc-Stangl, 1996 \\
\hline $\begin{array}{l}\text { US \& Canada, } \\
\text { C. 1993 }\end{array}$ & $95 \%$ & $2 *$ & $3^{*}$ & White \& M adara, 1994 \\
\hline
\end{tabular}

* includes some members with drug and other addictions and some overseas

** on a base of ex-alcoholic members.

$* * *$ small or non-existent 